\title{
Susceptibility of Severe Combined Immunodeficient (SCID) Mice to Mycobacterium leprae: Multiplication of the bacillus and dissemina- tion of the infection at early stage
}

\author{
YASUKo YOGI ${ }^{1)}$ KAZUNARI NAKAMURA ${ }^{1)}$ TUYoshi INOUE ${ }^{2)}$ Kunio KAWATSU ${ }^{1)}$ \\ YOSHIKO KASHIWABARA ${ }^{1)}$ YOSHIKI SAKAMOTO ${ }^{1 /}$ SHINZO IZUMI ${ }^{1)}$ \\ Muneo SAITO $^{3)}$ KyoJI HIOKI ${ }^{3)}$ TATHUJ NOMURA ${ }^{3)}$ \\ 1 : National Institute for Leprosy Research, Tokyo \\ 2 : National Defense Medical College, Tokorozawa \\ 3 : Central Institute for Experimental Animals, Kawasaki
}

(Received for publication:September 18,1991)

Key words : $M$. leprae, hind foot inoculation, SCID mouse, scid gene ; autosomal recessive mutation

Severe combined immunodeficient(SCID) mouse which are referred to the scid gene for autosomal recessive mutation was established by Bosma et al. in 1983. SCID mice which has lymphopenia are severely deficient in both $\mathrm{T}$ - and $\mathrm{B}$ cell immunity, histologic characteristics in mice are empty splenic follicles and lymph nodes. Additionally, Peyer's patches and solitary follicles of the intestinal tract are practically nonexistent. ${ }^{(1,2,3)}$

In the present study, we determined whether the susceptibility to Mycobacterium leprae of SCID mice is significant due to its severe immunodeficiency characteristics and whether it can be used as new animal model for the study of leprosy.

\section{Materials and Methods}

$\mathrm{SCID}(\mathrm{CB}-17 \mathrm{SCID} ;$ scid $/$ scid $), \mathrm{CB}-17(+/+)$ and $\mathrm{BALB} / \mathrm{cAJcl}$ mice were produced in the Central Institute for Experimental Animals. Twenty SCID mice of 4 weeks old were used. As controls 10 each of $\mathrm{CB}-17$ and $\mathrm{BALB} / \mathrm{cAJcl}$ mice of 4 weeks old were used, respectively. SCID mice were maintained in a vinyl isolator under specific pathogen-free $(\mathrm{SPF})$ conditions, and were provided with a sterilized autoclaved commercial diet (CE-2, CLEA JAPAN) and tap water ad libitum. CB-17 and BALB/cAJcl mice were housed in a conventional animal room with sterilized autoclavable pellets, water and beddings. The inoculum size of $M$. leprae, derived from footpad passage of nude mice was $4.8 \times 10^{6}$ bacilli. The inoculation was made at both the hind feet. Following the inoculation of $M$. leprae, the animals were sacrificed at varying periods of $3,5,7$ and 8 months after the inoculation. The right hind foot was used to count the number of bacilli and the left was used for histopathological examination. For the histopathology, the tissues obtained from the infected site of tested mice were fixed with $10 \%$ buffered formalin solution and processed for paraffin sections, and stained with Fite-Faraco's, Periodic acid-carbol pararosaniline (PA.CPR), Haematoxyline-Eosin(H \& E), Periodic acid shiff(PAS) and modified Jones silver 
stain. Besides, immunoglobulin levels of tested mice were determined by polyacrylamide gel electrophoresis(PAGE) and enzyme-linked immunosorbent assay (ELISA).

For identification of $M$. leprae, the harvested acid fast bacilli(AFB) from SCID mice which was inoculated 7 months earlier, were reinoculated into the right hind foot of $\mathrm{BALB} / \mathrm{cAJcl}$ mice in order to confirm the bacillary growth pattern. The AFB obtained were cultured on $1 \%$ Ogawa's medium(whole egg and egg yolk) at $33^{\circ} \mathrm{C}$ and $37^{\circ} \mathrm{C}$. Immunohistopathological stain with avidin-biotin-peroxidasecomplex (ABC) method was also done to confirm the presence of phenolic glycolipid(PGL).

\section{Results}

$M$. leprae was inoculated into both hind feet of SCID mice (male ; 10 , female ; 10), CB-17 mice (male : 5 , female ; 5) and BALB / cAJcl mice (male; 5 , female ; 5), the latter two being used as controls, and their susceptibility to $M$. leprae were assessed. The growth of $M$. leprae is shown in Table 1 as swelling of foot. Almost all of the SCID mice showed slight enlargement in injected foot at the day of 170 after inoculation, while the control CB-17 and BALB / CAJcl mice did not. Swelling of inoculated foot of SCID mice at the day of 240 after inoculation were measured $3.2-3.8 \mathrm{~mm}$ by peacook dial thickness gauge. Bacterial counts of $M$. leprae in right hind foot are shown in Table 2 at the time of 3,5,7 and 8 months after inoculation. The bacillary counts of the SCID mice increased to over inoculum size for approximately 3 months after inoculation as shown in the Table 2 . Subsequently, the tissues obtained from the infected left foot of mice were fixed in $10 \%$ buffered formalin solution and stained. Histopathological findings of infected foot of SCID mice 3 months after inoculation indicated the presence of bacilli around the blood vessels in the subcutaneous tissue and in the intermuscular layer on Fite-Faraco's or PA-CPR stains. Further multiplication of $M$. leprae in the injected foot of SCID mice were observed at the 5 months of inoculation, at that time, there was dissemination of the organisms from inoculated foot and so the bacilli extended to the neighbouring parts such as popliteal lymph nodes. Afterward, at 8 months after inoculation, the SCID mouse has more increasing number of $M$. leprae, their multiplication were observed all over the field including the inside of bone marrow at the injected site as shown in Fig. 1 and Fig. 2 . At this stage, as shown in Fig. 3 with Fite-Faraco's stain picture of giant globi observed in the muscular interstitial cells. When the same tissue observed by PAS stain(Fig. 4), the $M$. leprae were showing as if the picture of extreamely rapid proliferation in the phagocyted cells. Interestingly, there were also venules seen field with numerous $M$. leprae. Additionally, further multiplication of $M$. leprae in the draining lympho nodes was observed (Fig. 5), also dissemination of the bacilli from the site of inoculation in the both hind footpad was seen, though small in quantity, almost all over the body such as the external sacral or iliac nodes, the liver, the spleen, the lung and the base of tail, and then the case of male SCID mouse, the scrotum (gubernaculum), and the epididymis.

On the other hand, SCID mice lacked detectable immunoglobulins. Namely, when serum immunoglobulins determined by ELISA, the serum of tested SCID mouse revealed low levels of serum immunoglobulins in contrast to the normal levels in control mice. But $M$. leprae inoculated SCID mice showed high serum immunoglobulin levels than uninoculated them. Further studies are intended to clarified the relationship.

For identification of $M$. leprae, normal mice (BALB $/ \mathrm{cAJcl}$ ) were inoculated with the acid fast bacilli collected aseptically from the SCID mouse 7 months after inoculation. Cultivation of the bacilli on $1 \%$ Ogawa's medium(whole egg and egg yolk) at $33^{\circ} \mathrm{C}$ and $37^{\circ} \mathrm{C}$ was conducted. But the results of both the identification tests were negative. The presence of PGL was demonstrated at the site of multiplication 
of bacilli by immunohistopathological staining.

\section{Discussion}

Recently, several autoimmune euthymic mice bearing me, yee, $l p r$ and gld gene for single autosomalrecessive mutation were established by Jackson Laboratory, U.S.A. ${ }^{(4)}$ Additionally, one more euthymic CB-17SCID mouse carry the scid gene was established by Bosma et al., Fox Chase Cancer Center ${ }^{(1)}$.

Euthymic mice that spontaneouly impairs its immunity may be successful to on set of leprosy.

We have successfully established the euthymic mouse as an animal model for experimental leprosy ${ }^{(5,6)}$. Namely, the MRL/lpr mouse which spontaneously develop a progressive autoimmune disease such as glomerulonephritis, arteritis and arthritis. $\mathrm{C} 3 \mathrm{H} / \mathrm{lpr}$ and $\mathrm{B} 6 / \mathrm{lpr}$ mice which did not show the development of automimmune disease. Investigations were made to detect a possible difference in the role of genetic backgrounds. with $3 l p r$-bearing mice for growth of $M$. leprae. All of tested $l p r$-bearing mice were highly susceptible to $M$. leprae. Therefore, it can be concluded that the $l p r$ gene of these mice greatly enhanced the multiplication of $M$. leprae. On the other hand, in the present study, we have done inoculation with $M$. leprae in one more euthymic SCID mice which has undetectable serum immunoglobulin and containing a small number of thymic lymphocytes which express Thy $-1^{+}$and $\mathrm{IL}_{-}-2 \mathrm{R}{ }^{+}$but not Lyt $-2^{-}$or $\mathrm{L}_{3} \mathrm{~T}^{-}(1,2,3)$. As result of early experimental findings, SCID mice was found to have an extremely high susceptibility to $M$. leprae. The progress of infection observed in the SCID mice is considerably different showing a rapid progress of multiplication at the site of inoculation as well as the systemic spread of infection in contrast to the usual findings of athymic mice (undergoing). scid mutation gene will produce abnormarity in the rearrangement of DNA which will disturb the differentiation of $\mathrm{T}$ cell and B cell, ${ }^{(7,8)}$ and the resulting immunodeficiency of the SCID mouse is offering the multiplication of $M$. leprae. Presently, we are experimenting the reproducibility of the SCID mouse infection with $M$. leprae, in comparison with the findings of athymic (nude) mice, the possibility of systemic infection of through intraperitonary or intravenous infection will be made with the SCID mouse.

\section{Summary}

Inoculation of $M$. leprae were made into the both hind feet at a dose of $4.8 \times 10^{6}$ bacilli per foot in order to determine the susceptibility to $M$. leprae of SCID mice which is severely deficient in both $\mathrm{T}$ - and B cell immunity. SCID mice was found to have an extremely high susceptibility to $M$. leprae, and the progress of infection observed in the SCID mice were shown a rapid systemic spread of infection at the all over the tissues as well as the growth of the leprosy bacilli at the site of inoculation. Therefore, SCID mice can be used as a suitable multibacillary model for the study of leprosy.

\section{Acknowledgement}

This study was supported in part by U.S.-Japan Cooperative Medical Science Program. The results obtained were reported at the 64th General Meeting of Japanese Leprosy Association in Kumamoto, 1991. We also reported at the 26th U.S. -Japan Joint Conference on Leprosy and Tuberculosis Research in Seattle, Washington, 1991. 
Table 1.

Swelling of the hind footpads in SCID mice infected with $M$. leprae

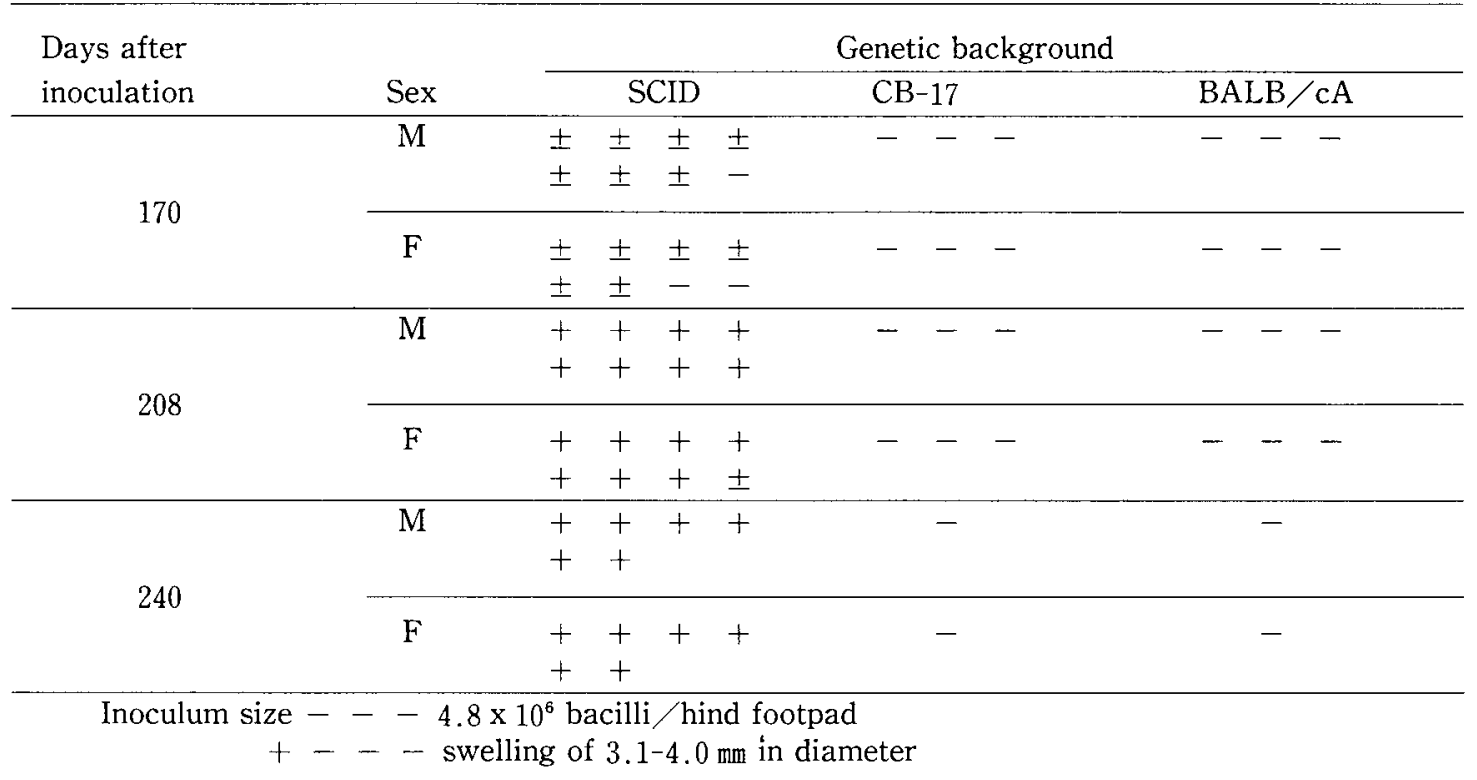

Table 2.

Number of $M$. leprae in right hind footpad of SCID, CB-17 and $\mathrm{BALB} / \mathrm{CA}$ mice at early stage after inoculation

\begin{tabular}{cccccc}
\hline \multirow{2}{*}{ Background } & Sex & \multicolumn{4}{c}{ Months after inoculation } \\
\cline { 3 - 6 } & & 3 & 5 & 7 & 8 \\
\hline SCID & $\mathrm{M}$ & $1.5 \times 10^{8}$ & $1.8 \times 10^{8}$ & $6.5 \times 10^{8}$ & $8.0 \times 10^{8}$ \\
& $\mathrm{~F}$ & $8.3 \times 10^{7}$ & $3.0 \times 10^{8}$ & $7.9 \times 10^{8}$ & $1.2 \times 10^{9}$ \\
\hline $\mathrm{CB}-17$ & $\mathrm{M}$ & $8.0 \times 10^{4}$ & $1.4 \times 10^{5}$ & $6.0 \times 10^{4}$ & $2.5 \times 10^{5}$ \\
& $\mathrm{~F}$ & $4.7 \times 10^{4}$ & $9.0 \times 10^{4}$ & $2.3 \times 10^{5}$ & $8.0 \times 10^{4}$ \\
\hline BALB $/ \mathrm{CA}$ & $\mathrm{M}$ & $5.0 \times 10^{4}$ & $2.0 \times 10^{5}$ & $4.0 \times 10^{5}$ & $1.2 \times 10^{5}$ \\
& $\mathrm{~F}$ & $9.5 \times 10^{4}$ & $1.2 \times 10^{5}$ & $1.0 \times 10^{5}$ & $2.0 \times 10^{5}$ \\
\hline
\end{tabular}

Inoculum size - - $4.8 \times 10^{6}$ bacilli $/$ hind footpad 


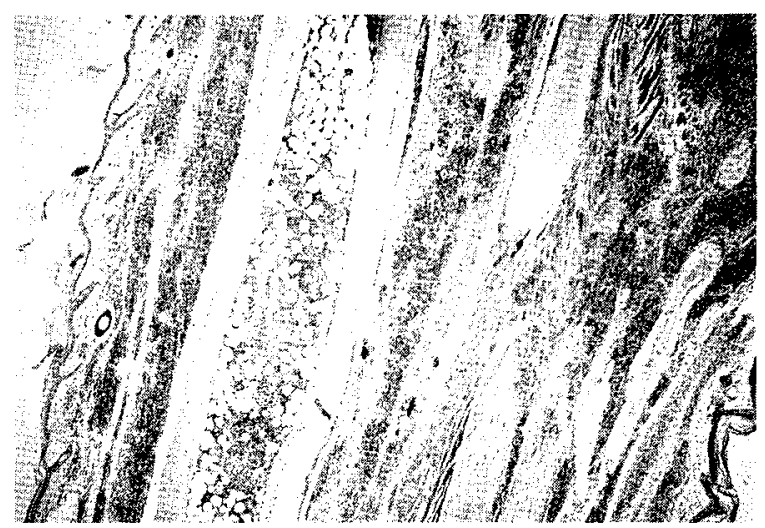

Fig. 1. Section of the inoculated foot in a SCID mouse on 8 months after inoculation with $M$. leprae. The multiplication of bacilli is observed all over the field including the inside bone marrow. Fite -Faraco's stain.

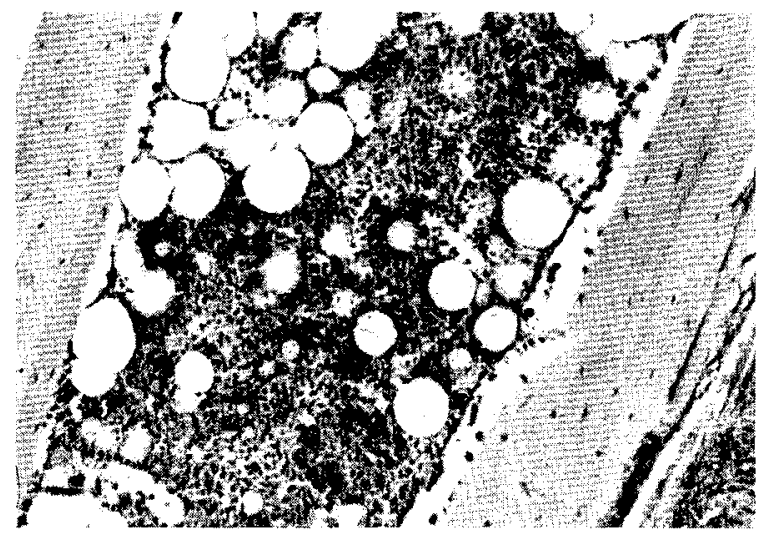

Fig. 2. The magnification of the inside of bone marrow in partial Fig. 1. A large number of acid-fast bacilli are observed in its with Fite-Faraco's stain.

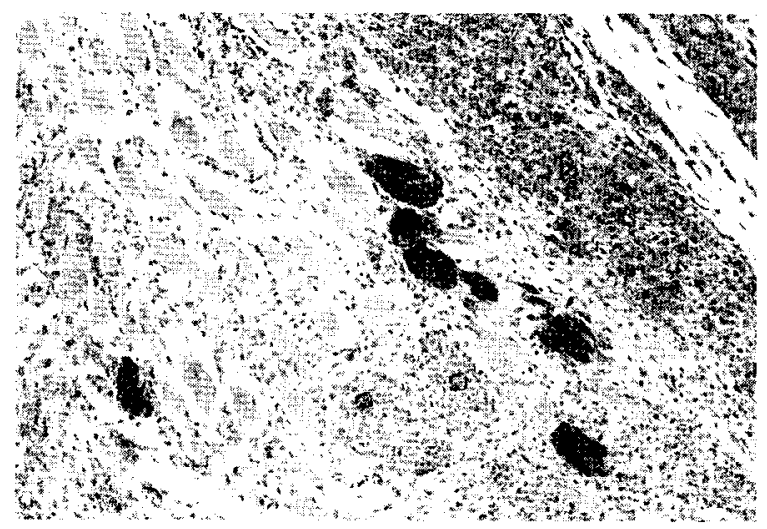

Fig. 3. Picture of giant globi observed in the muscular interstitial cells in a SCID mouse 8 months after inoculation. Fite-Faraco's stain. 


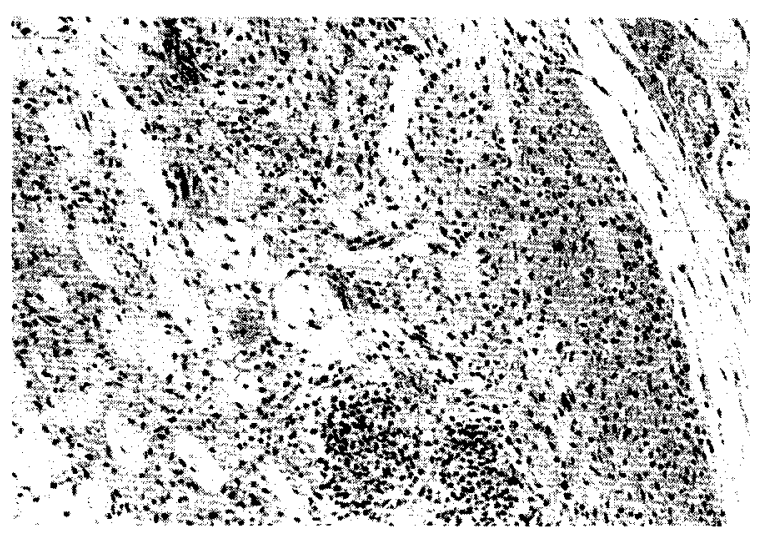

Fig. 4. A serial section of picture which showed Fig. 3. Periodic acid shiff stain.

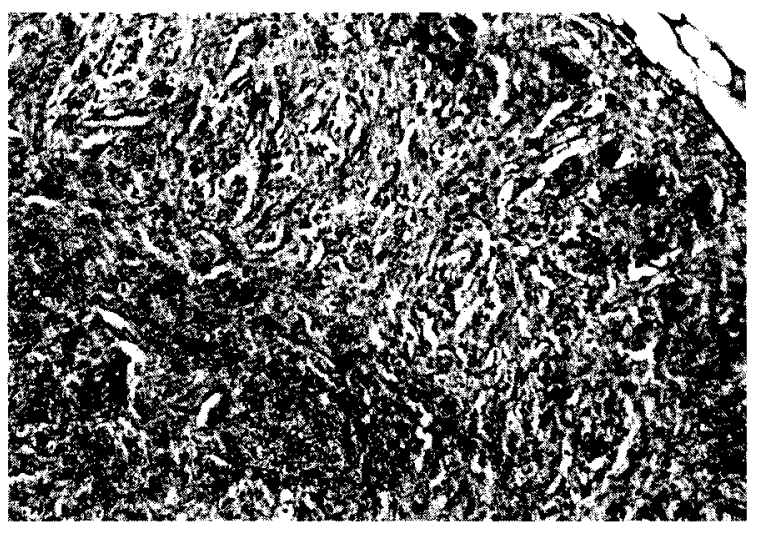

Fig. 5. A large number of increasing leprosy bacilli are seen in the popliteal lymph node of SCID mouse sacrificed on 8 months postinfection. PA-CPR stain.

\section{References}

1) Bosma, G.C.et al. : A severe combined immunodeficiency mutation in the mouse. Nature $301,527-530(1983)$

2) Habu, S.et al. : Correlation of $T$ cell receptor gene rearrangements to $T$ cell surface antigen expression and to serum immumoglobulin level in scid mice. Eur.J.Immunol., 17, 14671471(1987)

3 ) Custer, R.P.et al. : Severe combined immunodeficiency (SCID) in the mouse, Pathology, Reconstitution, Neoplasms. A.J.Pathol., 120, 464-477(1985)

4) Theofilopoulos, A.N. and Dixon, F. : Murine models of systemic lupus erythematosis. Adv. Immunol., 37, 269-390(1985) 
5) Yogi, Y. et al. : The experimental inoculation with Mycobacterium leprae in autoimmune mice : Results of MRL / lpr mice inoculated into the right hind foot (continued). Jap.J. Lepr., 58, 235-240 (1989)

6) Yogi, Y. et al. : The experimental inoculation with Mycobacterium leprae in autoimmune mice : Results of $\mathrm{C} 3 \mathrm{H} / l p r$ and $\mathrm{B} 6 / l p r$ mice inoculated into the right hind foot. Res. Activ. Natl. Inst. Lepr. Res., 35, 32-35(1989) (in Japanese)

7 ) Schuler, W.et al. : Rearrangement of antigen receptor genes is defective in mice with severe combined immune deficiency. Cell 46, 963(1986)

8 ) Blackwell, T.K. et al. : Isolation of scid pre-B cells that rearrange kappa light chain genes: formation of normal signal and abnormal coding joins. EMBO J., 8, 735-742(1989)

\section{重症複合型免疫不全症のモデル SCID マウスへのらい菌接種 早期の成績について}

$$
\begin{aligned}
& \text { 與 儀 ヤス子 }{ }^{1)} \text {, 中 村一 成 }{ }^{1)} \text {, 井上 健 }{ }^{2} \text {, 川津 邦 雄 }{ }^{11}
\end{aligned}
$$

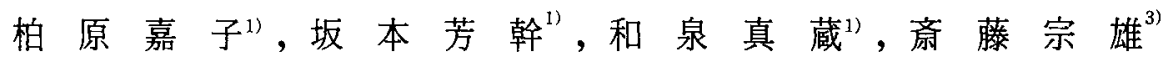

$$
\begin{aligned}
& \text { 日 置 恭 司 }{ }^{3)} \text {, 野 村 達 } \text { 次 }^{3)} \\
& 1 \text { ): 国立多摩研究所 2)：防衛医科大学校 } 3 \text { )：実験動物中央研究所 }
\end{aligned}
$$

キーワード：らい菌, 後肢足内接種, SCID マウス, scid（常染色体性劣性突然変異）遺伝子

ヒトの重症複合型免疫不全症に類似した症状を示 す有胸腺劣性突然変異 SCID マウスの両後肢足底内 に, $4.8 \times 10^{6}$ 個 /足のらい菌を接種して感受性の検討 を行った。免疫担当系組織が形態学的に末発達で, T細胞およびB細胞のほとんどの機能を欠如してい
るSCID マウスは，きわめて早期から全身感染像が 観察され，らい菌接種 8 ケ月目の接種足部では骨髄 内も含む足全体でのらい菌増殖像がみられる優れた 感受性能を示すマウスであることが分かった。 